\title{
Utilization of Iron Sand Waste and Bottom Ash as Alternate Concrete-making Materials
}

\author{
Iwan Rustendi*, Eddy Poerwodihardjo, Citra Pradipta Hudoyo \\ Faculty of Engineering, Universitas Wijayakusuma Purwokerto, Indonesia
}

Received February 25, 2020; Revised June 24, 2020; Accepted July 7, 2020

Copyright $\odot 2020$ by authors, all rights reserved. Authors agree that this article remains permanently open access under the terms of the Creative Commons Attribution License 4.0 International License

\begin{abstract}
Purpose: This Research to know whether the waste of iron sand and bottom ash can be used as substitute aggregate looks at the percentage of bottom ash and iron sand waste as fine aggregate for concrete production. The use of such waste as a material for making concrete will reduce waste that can pollute the environment. Methodology: The planned concrete compressing strength is $\mathrm{fc}$ ' $=20 \mathrm{Mpa}$ and the materials to be used are cement, water, sand as fine aggregate and gravel as coarse aggregate. This Research used 25 cylindrical concrete specimens with a variety of ages $3,7,14,21$, and 28 days. The process is divided into 6 stages: preparation, aggregate testing, planning (mix design), test specimen production, concrete curing and testing specimens. Results: The results of this Research stated that bottom ash and iron sand waste could be used as a substitution of fine aggregate for making concrete. Based on several tests, the ratio of iron sand waste and bottom ash which is the closest to the gradation of zone 2 (ideal zone) is the percentage of the iron sand waste mixture of $40 \%-60 \%$ bottom ash that enters zone 2 (rather rough). Suggestions for further Research are to use coarse aggregate whose size varies and use admixture in concrete mixtures. Applications/Originality/Value: Expectations from this Research can provide benefits, among others, can reduce the environmental impact of waste to the surrounding community and provide information for the dive the world community, especially the construction of the benefits and usefulness of iron sand waste and bottom ash as a building material.
\end{abstract}

Keywords Iron Sand Waste, Bottom Ash, Concrete, Compressive Strength

\section{Introduction}

The need for concrete for construction is increasing, and at the same time as natural aggregates are decreasing in various regions, which creates an urgent need to consider substitute materials for aggregates in concrete. This great need led researchers to look for alternative materials by using waste materials, by-products and recyclables. (Ravindrarajah \& Tam, 1987); (Dayalan \& Beulah, 2014).

Fly ash and bottom ash are waste from power plants that use coal as an energy source. Such waste that continues to accumulate can result in environmental pollution (Darwis, Soelarso, \& Hidayat, 2015). Coal ash obtained from the bottom of the furnace commonly referred to as coal bottom ash (CBA). This ash is heavier and more difficult to be carried by exhaust gases compared to fly ash, as discussed by Bajara et al. (2013), Menéndez et al. (2014) and Singh et al. (2013).

Industrial waste such as iron sand waste for steel production can be dangerous for the environment. Stockpiling this material near the production site can cause soil and groundwater contamination (Ghannam, Najm, \& Vasconez, 2016). In Karangkandri Village, Cilacap, Central Java, there is an iron sand mining industry which is now inactive, but iron sand waste remains. The processing of iron sand waste in Karangkandri Village has not been fully utilized, and in Karangkandri Village, iron sand waste is only used as rice fill material.

Being around coal ash dumps can increase the probability of getting cancer and other diseases. The waste can also affect the quality of drinking water from wells, where humans can get cancer because they drink water that has been contaminated with arsenic (EPA. 2007).

Coal waste and iron sand waste generated from day to day always increase. If this much waste is not treated, it will cause problems, and one of which is environmental pollution. Utilization of waste is one of the ideal alternatives to overcome the problem of waste (Ramzi et al. 2016). Because it can ease the cost of disposal and reduce adverse effects on the environment, nevertheless, the strategy should be paid attention to in terms of the utilization of environment and energy to use available materials efficiently (Alzaed, 2014). 


\section{Literature Review}

There have been several previous studies that used material substitutes in concrete production. Research is to find out whether ceramic waste can be used as a substitute for aggregate. The results obtained are the use of ceramic waste for the manufacture of concrete turned out to be quite effective and efficient (Ramadevi, 2017).

Research by replacing fine aggregate, which generally uses normal sand with GGBS (impact heater granulated slag). The substitution of the fine total by GGBS is in the scope of $0 \%$ (without GGBS), $5 \%, 10 \%$ and $15 \%$. Concrete blends were blended totally, tried and discover the compressive, flexural and split rigidity are contrasted and the customary cement (Manhas \& Moohmend, 2018).(Please rephrase the sentence)

Research by using iron sand as a substitute for cement against the compressive strength and tensile strength of concrete is done. Iron sand containing $\mathrm{Fe} 2 \mathrm{O} 3, \mathrm{SiO} 2, \mathrm{MgO}$ and 80-100 mesh concrete sizes has the potential to be used as a substitute for cement in the production of high-performance concrete as discussed by Lufti (2012).

Research by using Bottom Ash as an additional ingredient in the manufacture of concrete with seawater immersion, then revealed the concrete is stronger. In essence, this study aims to determine the effect of a mixture of species of cement paste with bottom ash to the compressive strength of concrete with a variety of mix percentage of $0 \%, 10 \%, 20 \%, 25 \%$, with the immersion of seawater on the duration of 7,14 , and 28 days. The results of this study are derived from following factors. Levels mix Bottom Ash and seawater soaking time on the concrete cylinders showed that the addition of Bottom Ash as a cement substitute as much as $10 \%$ had elevated concrete strength of regular concrete (Bottom Ash content $0 \%$ ) of $1.95 \mathrm{MPa}$ for immersion 7 days, $3.87 \mathrm{MPa}$ to soak 14 days, $0.5 \mathrm{MPa}$ for 28 days immersion. And compressive strength in the bath 14 days and 28 days decreased the strength of concrete, which is not significant, as discussed by Arinata, Hidayat, \& Wibowo (2014).

This Research replaced sand with WFS (waste foundry sand) and then analyzed the strength and durability of concrete. The results of the test have shown that using WFS as a substitute for fine aggregate increased the strength and durability of the concrete (Ramesh, Lokeswari, \& Ravitheja, 2018).

The Research used ground Low-Density Poly Propylene (LDPP) bags as a substitute for fine aggregate in the manufacture of concrete. Replacement with the proportion of $5 \%, 10 \%, 15 \%$ and $20 \%$ of fine aggregate. The test result is that a mixture with a portion of $10 \%$ of LDPP gets better strength, stress and flexibility than conventional concrete (Sreenath \& Harishankar, 2016).

According to Alzaed (2014), the effect of iron filing on concrete can increase the compressive strength of concrete. Several formulas are used in Research to find the percentage of iron in making concrete. The result of the study is that the compressive strength of concrete increases by $17 \%$ when $30 \%$ of iron is added to the concrete mixture. At the same time, the tensile strength of concrete has only a slight effect if the percentage of iron filling in the concrete mix reaches more than $10 \%$. The tensile strength of concrete is increased by $13 \%$ when adding $10 \%$ iron filling to the concrete mixture.

A Research using Bottom Ash as an additional mixture in the manufacture of concrete with seawater immersion then tested the strength of the concrete. Basically, it is to determine the effect of a mixture of cement paste species with bottom ash on the compressive strength value of concrete with a variation of the mixture percentage of $0 \%$, $10 \%, 20 \%, 25 \%$, with seawater immersion. The results of this Research obtained by a factor of mixed bottom ash content and seawater immersion time in a concrete cylinder showed that the addition of bottom ash as a substitute for cement by $10 \%$ has an increase in the strength of concrete than standard concrete (bottom ash $0 \%$ content) as much as 1.95 $\mathrm{MPa}$ for immersion 7 days, $3.87 \mathrm{MPa}$ for 14-day immersion, 0.5 MPa for 28-day immersion. And for compressive strength at 14 days and 28 days immersion did not significantly decrease the strength of concrete as discussed Arinata, Hidayat, \& Wibowo (2014).

\section{Materials}

\section{Cement}

This study uses OPC (Ordinary Portland Cement) Type I that probably is the most familiar around you because it is most widely used by the wider community and circulating in the market. This type is commonly used for general building construction that does not require specific requirements for heat hydration and initial press force. The uses of Portland Type I Cement include building construction for residential houses, terraced buildings, and highways, which is suitable for use in soil and water containing sulphate $0,0 \%-0,10 \%$. Below is a cement type resistant table (U.S. Bureau of Reclamation, 1981): 
Table 1. Attack on Concrete by Soils and Waters Containing Various Sulfate Concentration

\begin{tabular}{cccc}
\hline $\begin{array}{c}\text { Relative Degree of } \\
\text { Sulfate Attack }\end{array}$ & $\begin{array}{c}\text { Percentage Water-Soluble Sulfate } \\
\text { (as S04) in Soil Samples }\end{array}$ & $\begin{array}{c}\text { Sulfate (as S04) in Water } \\
\text { Samples, Ppm }\end{array}$ & Cement Type \\
\hline Negligible & 0.00 to 0.10 & 0 to 150 & I \\
Positive & 0.10 to 0.20 & 150 to 1500 & II \\
Severe & 0.20 to 2.00 & 1500 to 10000 & V \\
Very Severe & 2.00 or more & 10000 or more & V + pozzolan \\
\hline
\end{tabular}

\section{Iron Sand}

Iron sand is sand deposition containing iron particles (magnetite) found along the coast. In the processing of iron sand in the industrial world will produce iron powder waste or iron sand waste (Ghannam, Najm, \& Vasconez, 2016). In this Research used iron sand waste is from Karangkandri village, Cilacap, Indonesia.

\section{Bottom Ash}

Bottom ash is ash which is produced when coal combustion settles (Kumari \& Thandavamoorthy, 2017). Coal ash requires proper management so as not to cause environmental pollution and. This coal ash requires a spacious and safe shelter with a high handling cost.

\section{Coarse Aggregate}

This study uses coarse aggregate from the Klawing river in Purbalingga with a size of no more than $20 \mathrm{~mm}$.

\section{Water}

The function of water in a concrete mixture is to help chemical reactions that cause the binding process and as a lubricant between the aggregate and cement mixture so that it is easy to work on.

\section{Methodology}

This research was conducted in a laboratory to make 25 cylindrical concrete samples with a size of $15 \times 30 \mathrm{~cm}$, and there are several steps done, such as:

\section{Preparation}

This stage prepares the materials used in this research, such as:

- $\quad$ Ordinary Portland Cement Type I

- Iron sand waste from Karangkandri village, Cilacap, Indonesia

- Coarse aggregate from the Klawing river, Purbalingga, Indonesia

- Bottom Ash from a thermal power station in Jepara, Indonesia

\section{Aggregate Testing}

This test method is based on SNI 03-1968-1990 (Fine and Coarse Aggregates, Sieve Analysis Test Method), SNI 03-1970-1990 (Aggregate Fine Test Methods specific gravity and Water Absorption) and SNI 2417: 2008 (About How to Test Aggregate Wear with Los Angeles Abrasion Machines).

\section{Planning (Mix Design)}

Calculations to determine the proportion of each aggregate in each condition, the value of the slump plan and the number of test objects is made that is as many as 25 pieces consisting of 5 test pieces for each age plan 3, 7, 14, 21 , and 28 days.

\section{Test Specimens Production (Mixing Process)}

After knowing the proportions, the materials are weighed according to their needs to be stirred in a concrete mixer for 3-5 minutes, then whether the slump value is in accordance with the plan slump value is tested, then the concrete mould is mixed in a $15 \mathrm{~cm} \times 30 \mathrm{~cm}$ cylinder, and when filled the cylinder is divided into three layers and each layer is pounded with iron 25 times with $\varnothing 16 \mathrm{~mm}$ iron, the mould is filled to be full until it is flattened.

\section{Concrete Curing}

Wait for the concrete mixture on the cylinder mold for 24 hours, and then remove the mould. After that, the sample totally immersed in water. Five groups with every 5 samples were then taken from the water at the age of planned $(3,7,14,21$, and 28 days) for the concrete compressive strength test.

\section{Testing Specimens}

Concrete compressive strength testing is done at the age of $3,7,14,21$, and 28 days for each concrete specimen. The equation used:

$$
f \mathrm{c}^{\prime}=\frac{P}{A}
$$

where:

$f \mathrm{c}^{\prime}=$ Compressive strength $(\mathrm{MPa})$ 
$\mathrm{P}=$ Maximum load $(\mathrm{N})$

$\mathrm{A}=$ Area of the press $\left(\mathrm{mm}^{2}\right)$

\section{Result and Discussion}

\section{Material Testing}

\section{Fine Aggregate Testing}

The percentage gradation of the mixture of iron sand and bottom ash waste used is included in the Zone 2 sand gradation (ideal sand gradation). Based on the test results, the percentage included in zone 2 is the percentage of iron sand waste $40 \%-60 \%$ bottom ash.

The test results of the specific gravity test for iron sand waste is 3.20. These results indicate that iron sand waste aggregate is included in the heavy aggregate. The bottom ash density test result is 2.12 , and it shows that the bottom ash density is a mild aggregate. The results of the specific gravity test percentage of iron sand waste is $40 \%-60 \%$ with bottom ash 2.58. These results indicate that the percentage of weight is included in the normal aggregate.

Fine aggregates for building materials (except Special Aggregates, for example, light aggregates and so on) good fine aggregates do not have a mud content of more than 5\% (General regulations on building materials in Indonesia 1982 , article 11 page 17). If the mud content exceeds $5 \%$, it must be washed first. Based on the results of testing the level of iron sand waste sludge obtained value of $1.80 \%$ while the bottom ash sludge testing results obtained amount of $0.76 \%$.

\section{Coarse Aggregate Testing}

Coarse aggregate tests performed include the coarse aggregate specific gravity and rough aggregate wear. Coarse aggregate gradation is not carried out because the coarse aggregate (gravel) used is a maximum size of $20 \mathrm{~mm}$ originating from the Klawing River, Purbalingga, Indonesia.

The results of specific gravity tests obtained at 2.74 are categorized as average aggregate. Based on SNI 03-2417-1991 (Aggregate Wear Test Method with Los Angeles Abrasion Machine) the good value of aggregate wear to be used is $<40 \%$. From the testing of coarse aggregate wear by using a Los Angeles machine, the wear value is $32.25 \%$. Therefore the coarse aggregate derived from Klawing River, and Purbalingga is a suitable aggregate in concrete manufacture.

\section{Aggregate Testing Result Data}

Table 2 shows the data of aggregate test results, including data on gradation test results, specific gravity, sludge content for fine aggregate while rough aggregate is tested for specific gravity and gravel wear.

Based on the gradation test results, the percentage of fine aggregate entering zone 2 (ideal zone) is the percentage of iron sand waste $40 \%-60 \%$ bottom ash.

Table 2. Aggregate Testing Result Data

\begin{tabular}{cccc}
\hline \multirow{2}{*}{ Test } & \multicolumn{2}{c}{ Fine Aggregate } & $\begin{array}{c}\text { Coarse } \\
\text { Aggregate }\end{array}$ \\
\cline { 2 - 4 } & $\begin{array}{c}\text { Iron Sand } \\
\text { Waste }\end{array}$ & Bottom Ash & Gravel \\
\hline Gradation & Zona 4 & Zona 2 & Max. 20 Mm \\
Specific gravity & 3,2 & 2,12 & 2,74 \\
Sludge levels & $1,80 \%$ & $0,76 \%$ & - \\
Gravel wear & - & - & $32,25 \%$ \\
\hline
\end{tabular}

\section{Slump Test}

In testing the slump, the test has been performed 2 times. The results of the slump test can be seen in Table 3 .

Table 3. Slump Test Result

\begin{tabular}{cccc}
\hline \multicolumn{4}{c}{ Slump Test Result } \\
\hline Mix 1 & Mix 2 & Average & Information \\
\cline { 1 - 2 } 3 cylinder & 2 cylinder & & $\begin{array}{c}\text { To Be Tested on } \\
\text { Concrete Age (days) }\end{array}$ \\
\hline (cm) & $(\mathbf{c m})$ & $(\mathbf{c m})$ & \\
\hline 8 & 8 & 8 & 3 \\
8 & 8 & 8 & 7 \\
10 & 10 & 10 & 14 \\
8 & 8 & 8 & 21 \\
8 & 8 & 8 & 28 \\
\hline
\end{tabular}

Based on the results of the slump test obtained ranged from $8 \mathrm{~cm}-10 \mathrm{~cm}$, while in the planning of concrete mix (mix design) $10 \pm 2 \mathrm{~cm}$, the value of the slum test has met the plan.

\section{Concrete Compressive Strength}

This test is carried out in $3,7,14,21$, and 28 days for each concrete specimen. Concrete compressive strength test results can be seen in table 4 . 
Table 4. Concrete Compressive Strength Test Results (3 days)

\begin{tabular}{|c|c|c|c|c|c|c|c|}
\hline \multirow{2}{*}{ No. } & \multirow{2}{*}{$\begin{array}{c}\text { Test Object } \\
\text { Code }\end{array}$} & \multirow{2}{*}{$\begin{array}{l}\text { Weight } \\
\text { (gram) }\end{array}$} & \multicolumn{2}{|c|}{ Maximum load (P) } & \multirow{2}{*}{$\begin{array}{l}\text { Area of Press (A) } \\
(\mathbf{m m})\end{array}$} & \multirow{2}{*}{$\begin{array}{l}\text { Compressive } \\
\text { strength } \\
\text { (MPa) }\end{array}$} & \multirow{2}{*}{$\begin{array}{c}\text { Estimated } \\
\text { compressive strength } \\
\text { at } \\
28 \text { days (MPa) } \\
\end{array}$} \\
\hline & & & $(\mathbf{K g})$ & $(\mathbf{N})$ & & & \\
\hline 1 & SP1.3 & 12.270 & 19.000 & 186.390 & 17662,5 & 10,55 & 22,94 \\
\hline 2 & SP2.3 & 12.370 & 22.000 & 215.820 & 17662,5 & 12,22 & 26,56 \\
\hline 3 & SP3.3 & 12.200 & 21.400 & 209.934 & 17662,5 & 11,89 & 25,84 \\
\hline \multicolumn{6}{|c|}{ Average Compressive Strength } & 11,55 & 25,11 \\
\hline
\end{tabular}

Note : cylinder conversion age 28 days from age 3 days (divided) $=0.46$

Table 5. Concrete Compressive Strength Test Results (7 days)

\begin{tabular}{|c|c|c|c|c|c|c|c|}
\hline \multirow{2}{*}{ No. } & \multirow{2}{*}{$\begin{array}{l}\text { Test Object } \\
\text { Code }\end{array}$} & \multirow{2}{*}{$\begin{array}{l}\text { Weight } \\
\text { (gram) }\end{array}$} & \multicolumn{2}{|c|}{ Maximum load (P) } & \multirow{2}{*}{$\begin{array}{l}\text { Area of Press (A) } \\
(\mathbf{m m})\end{array}$} & \multirow{2}{*}{$\begin{array}{l}\text { Compressive } \\
\text { strength } \\
\text { (MPa) }\end{array}$} & \multirow{2}{*}{$\begin{array}{c}\text { Estimated } \\
\text { compressive strength } \\
\text { at } \\
28 \text { days (MPa) }\end{array}$} \\
\hline & & & $(\mathbf{K g})$ & $(\mathbf{N})$ & & & \\
\hline 1 & SP1.7 & 12.340 & 32.000 & 313.920 & 17662,5 & 17,77 & 25,39 \\
\hline 2 & SP2.7 & 12.250 & 33.000 & 323.730 & 17662,5 & 18,33 & 26,18 \\
\hline 3 & SP3.7 & 12.190 & 32.000 & 313.920 & 17662,5 & 17,77 & 25,39 \\
\hline \multicolumn{6}{|c|}{ Average Compressive Strength } & 17,96 & 25,65 \\
\hline
\end{tabular}

Note : cylinder conversion age 28 days from age 7 days (divided) $=0.70$

Table 6. Concrete Compressive Strength Test Results (14 days)

\begin{tabular}{|c|c|c|c|c|c|c|c|}
\hline \multirow{2}{*}{ No. } & \multirow{2}{*}{$\begin{array}{l}\text { Test Object } \\
\text { Code }\end{array}$} & \multirow{2}{*}{$\begin{array}{l}\text { Weight } \\
\text { (gram) }\end{array}$} & \multicolumn{2}{|c|}{ Maximum load (P) } & \multirow{2}{*}{$\begin{array}{c}\text { Area of Press (A) } \\
(\mathbf{m m})\end{array}$} & \multirow{2}{*}{$\begin{array}{c}\text { Compressive } \\
\text { strength } \\
\text { (MPa) }\end{array}$} & \multirow{2}{*}{$\begin{array}{c}\text { Estimated } \\
\text { compressive strength } \\
\text { at } \\
28 \text { days (MPa) } \\
\end{array}$} \\
\hline & & & $(\mathbf{K g})$ & $(\mathrm{N})$ & & & \\
\hline 1 & SP1.14 & 12.220 & 37.000 & 362.970 & 17662,5 & 20,55 & 23,35 \\
\hline 2 & SP2.14 & 12.360 & 43.400 & 425.754 & 17662,5 & 24,10 & 27,39 \\
\hline 3 & SP3.14 & 12.280 & 39.000 & 382.590 & 17662,5 & 21,66 & 24,61 \\
\hline \multicolumn{6}{|c|}{ erage Compressive Strength } & 22,11 & 25,12 \\
\hline
\end{tabular}

Note : cylinder conversion age 28 days from age 14 days (divided) $=0.88$

Table 7. Concrete Compressive Strength Test Results (21 days).

\begin{tabular}{|c|c|c|c|c|c|c|c|}
\hline \multirow{2}{*}{ No. } & \multirow{2}{*}{$\begin{array}{l}\text { Test Object } \\
\text { Code }\end{array}$} & \multirow{2}{*}{$\begin{array}{l}\text { Weight } \\
\text { (gram) }\end{array}$} & \multicolumn{2}{|c|}{ Maximum load (P) } & \multirow{2}{*}{$\begin{array}{c}\text { Area of Press (A) } \\
\qquad(\mathbf{m m})\end{array}$} & \multirow{2}{*}{$\begin{array}{c}\text { Compressive } \\
\text { strength } \\
\text { (MPa) }\end{array}$} & \multirow{2}{*}{$\begin{array}{c}\text { Estimated } \\
\text { compressive } \\
\text { strength at } \\
28 \text { days (MPa) }\end{array}$} \\
\hline & & & $(\mathbf{K g})$ & $(\mathbf{N})$ & & & \\
\hline 1 & SP1.21 & 12.370 & 45.000 & 441.450 & 17662,5 & 24,99 & 26,04 \\
\hline 2 & $\mathrm{SP} 2.21$ & 12.400 & 45.000 & 441.450 & 17662,5 & 24,99 & 26,04 \\
\hline 3 & SP3.21 & 12.330 & 43.000 & 421.830 & 17662,5 & 23,88 & 24,88 \\
\hline \multicolumn{6}{|c|}{ Average Compressive Strength } & 24,62 & 25,65 \\
\hline
\end{tabular}

Note : cylinder conversion age 28 days from age 21 days (divided) $=0.96$

Table 8. Concrete Compressive Strength Test Results (28 days)

\begin{tabular}{|c|c|c|c|c|c|c|}
\hline \multirow{2}{*}{ No. } & \multirow{2}{*}{$\begin{array}{l}\text { Test Object } \\
\text { Code }\end{array}$} & \multirow{2}{*}{$\begin{array}{l}\text { Weight } \\
\text { (gram) }\end{array}$} & \multicolumn{2}{|c|}{ Maximum load (P) } & \multirow{2}{*}{$\begin{array}{c}\text { Area of Press (A) } \\
(\mathbf{m m})\end{array}$} & \multirow{2}{*}{$\begin{array}{c}\text { Compressive strength } \\
\text { (MPa) }\end{array}$} \\
\hline & & & $(\mathrm{Kg})$ & $(\mathbf{N})$ & & \\
\hline 1 & SP1.28 & 12.330 & 52.500 & 515.025 & 17662,5 & 29,16 \\
\hline 2 & SP2.28 & 12.370 & 48.000 & 470.880 & 17662,5 & 26,66 \\
\hline 2 & SP3.28 & 12.400 & 48.000 & 470.880 & 17662,5 & 26,66 \\
\hline \multicolumn{6}{|c|}{ Average Compressive Strength } & 27,49 \\
\hline
\end{tabular}


The test results above are then made a graph of the results of the compressive strength test, as in Figure 1.

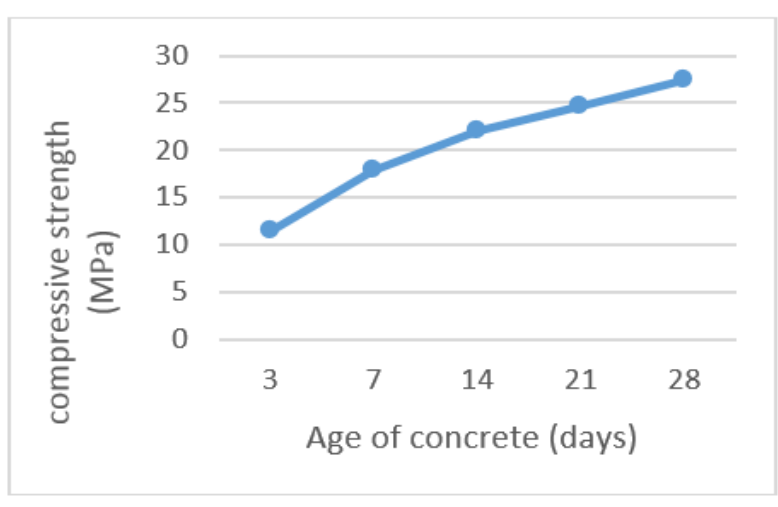

Figure 1. Graph of concrete compressive strength at various ages

Based on figure 1, the more concrete the age of the concrete, the more reliable the strength will be. At the age of 3 days, the concrete compressive strength reached 12.37 $\mathrm{MPa}$, age 7 days increased $54.49 \%$ to $19.11 \mathrm{MPa}$, at 14 days increased $29.62 \%$ to $24.77 \mathrm{MPa}$, age 21 increased $1.57 \%$ to $25.16 \mathrm{MPa}$, and age 28 increased $5.29 \%$ to 26.49 MPa. It can be concluded that the results of the compressive strength test of the average age of 28 reached the characteristic compressive strength of f'c $20 \mathrm{Mpa}$ but did not reach the plan compressive strength of $32 \mathrm{MPa}$ f'cr. One factor why the average compressive strength has not yet reached the plan compressive strength of $32 \mathrm{MPa} \mathrm{f}^{\prime} \mathrm{cr}$ is the fine aggregate gradation of the percentage of iron sand waste $40 \%-60 \%$ bottom ash does not fully enter zone 2 (ideal zone).

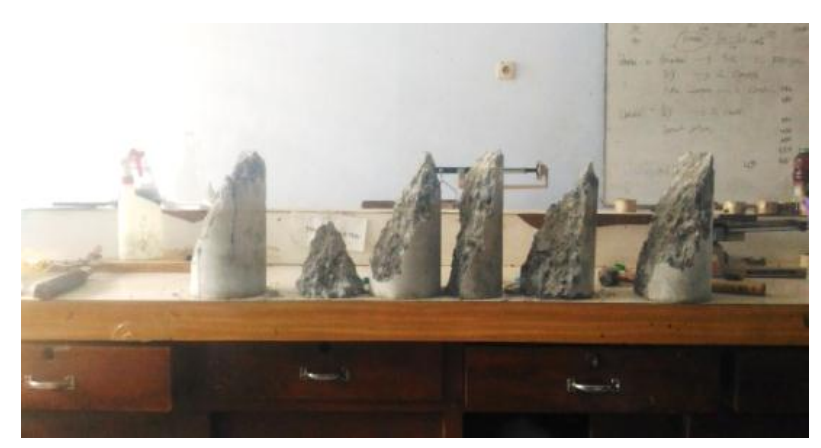

Figure 2. Broken Concrete Generated Pattern

The characteristic of a good concrete that can be seen from the pattern of broken concrete is a good breaking pattern that is broken diagonally / not broken into pieces. From the results of the concrete compressive strength test in the Laboratory, the pattern of rupture produced by tilting / not broken into pieces as in figure 2. Concrete with good quality-tested will sound with a quite loud explosion. Strength test that is made a loud explosion.

\section{Concrete Specific Gravity}

The specific density of concrete at 3, 7, 14, 21, 28 days are as follows:

Table 9. Calculation Result of Average Concrete Specific Gravity (3 days)

\begin{tabular}{|c|c|c|c|c|c|}
\hline \multirow{2}{*}{ No. } & \multirow{2}{*}{ Test Object Code } & \multicolumn{2}{|c|}{ Weight } & \multirow{2}{*}{ Volume } & \multirow{2}{*}{$\begin{array}{c}\text { Concrete Specific Gravity } \\
\qquad\left(\mathrm{kg} / \mathrm{m}^{3}\right)\end{array}$} \\
\hline & & gram & kg & & \\
\hline 1 & SP1.3 & 12.270 & 12,27 & 0,0053 & 2.315 \\
\hline 2 & $\mathrm{SP} 2.3$ & 12.370 & 12,37 & 0,0053 & 2.334 \\
\hline 3 & SP3.3 & 12.200 & 12,2 & 0,0053 & 2.302 \\
\hline 4 & SP4.3 & 12.250 & 12,25 & 0,0053 & 2.311 \\
\hline 5 & SP5.3 & 12.130 & 12,13 & 0,0053 & 2.289 \\
\hline \multicolumn{5}{|c|}{ Average Specific Gravity } & 2.310 \\
\hline
\end{tabular}

Table 10. Calculation Result of Average Concrete Specific Gravity (7 days)

\begin{tabular}{|c|c|c|c|c|c|}
\hline \multirow{2}{*}{ No. } & \multirow{2}{*}{ Test Object Code } & \multicolumn{2}{|c|}{ Weight } & \multirow{2}{*}{ Volume } & \multirow{2}{*}{ Concrete Specific Gravity $\left(\mathrm{kg} / \mathrm{m}^{3}\right)$} \\
\hline & & gram & kg & & \\
\hline 1 & SP1.7 & 12.180 & 12,18 & 0,0053 & 2.298 \\
\hline 2 & SP2.7 & 12.340 & 12,34 & 0,0053 & 2.328 \\
\hline 3 & SP3.7 & 12.250 & 12,25 & 0,0053 & 2.311 \\
\hline 4 & SP4.7 & 12.190 & 12,19 & 0,0053 & 2.300 \\
\hline 5 & SP5.7 & 12.370 & 12,37 & 0,0053 & 2.334 \\
\hline \multicolumn{5}{|c|}{ Average Specific Gravity } & 2.314 \\
\hline
\end{tabular}


Table 11. Calculation Result of Average Concrete Specific Gravity (14 days)

\begin{tabular}{|c|c|c|c|c|c|}
\hline \multirow{2}{*}{ No. } & \multirow{2}{*}{ Test Object Code } & \multicolumn{2}{|c|}{ Weight } & \multirow{2}{*}{ Volume } & \multirow{2}{*}{ Concrete Specific Gravity $\left(\mathrm{kg} / \mathrm{m}^{3}\right)$} \\
\hline & & gram & kg & & \\
\hline 1 & SP1.14 & 12.060 & 12,06 & 0,0053 & 2.275 \\
\hline 2 & SP2.14 & 12.220 & 12,22 & 0,0053 & 2.306 \\
\hline 3 & SP3.14 & 12.360 & 12,36 & 0,0053 & 2.332 \\
\hline 4 & SP4.14 & 12.280 & 12,28 & 0,0053 & 2.317 \\
\hline 5 & SP5.14 & 12.280 & 12,28 & 0,0053 & 2.317 \\
\hline \multicolumn{5}{|c|}{ Average Specific Gravity } & 2.309 \\
\hline
\end{tabular}

Table 12. Calculation Result of Average Concrete Specific Gravity (21 days)

\begin{tabular}{|c|c|c|c|c|c|}
\hline \multirow{2}{*}{ No. } & \multirow{2}{*}{ Test Object Code } & \multicolumn{2}{|c|}{ Weight } & \multirow{2}{*}{ Volume } & \multirow{2}{*}{ Concrete Specific Gravity $\left(\mathrm{kg} / \mathrm{m}^{3}\right)$} \\
\hline & & gram & kg & & \\
\hline 1 & SP1.21 & 12.330 & 12,33 & 0,0053 & 2.326 \\
\hline 2 & SP2.21 & 12.370 & 12,37 & 0,0053 & 2.334 \\
\hline 3 & SP3.21 & 12.400 & 12,4 & 0,0053 & 2.340 \\
\hline 4 & SP4.21 & 12.330 & 12,33 & 0,0053 & 2.326 \\
\hline 5 & SP5.21 & 12.220 & 12,22 & 0,0053 & 2.306 \\
\hline \multicolumn{5}{|c|}{ Average Specific Gravity } & 2.326 \\
\hline
\end{tabular}

Table 13. Calculation Result of Average Concrete Specific Gravity (28 days)

\begin{tabular}{|c|c|c|c|c|c|}
\hline \multirow{2}{*}{ No. } & \multirow{2}{*}{ Test Object Code } & \multicolumn{2}{|c|}{ Weight } & \multirow{2}{*}{ Volume } & \multirow{2}{*}{ Concrete Specific Gravity $\left(\mathrm{kg} / \mathrm{m}^{3}\right)$} \\
\hline & & gram & kg & & \\
\hline 1 & SP1.28 & 12.240 & 12,24 & 0,0053 & 2.309 \\
\hline 2 & $\mathrm{SP} 2.28$ & 12.300 & 12,3 & 0,0053 & 2.321 \\
\hline 3 & SP3.28 & 12.310 & 12,31 & 0,0053 & 2.323 \\
\hline 4 & SP4.28 & 12.650 & 12,65 & 0,0053 & 2.387 \\
\hline 5 & SP5.28 & 12.350 & 12,35 & 0,0053 & 2.330 \\
\hline \multicolumn{5}{|c|}{ Average Specific Gravity } & 2.334 \\
\hline
\end{tabular}

Based on SNI 03-2834-2000 (Procedure for Normal Concrete Plan) normal concrete density ranges between 2200 to $2500 \mathrm{~kg} / \mathrm{m} 3$, from the calculation of the average density of concrete age of $3,7,14,21,28$ days served in Table 8 through Table 12 directing that the resulting concrete into normal concrete and an average specific gravity density concrete planned approach that is $2,383 \mathrm{~kg} /$ $\mathrm{m} 3$.

\section{Conclusions}

Based on the results of Research that has been done, it can be concluded that:

- Based on the results of grading tests, specific gravity, sludge content and compressive strength values generated that the waste of bottom ash and iron sand waste can be used as fine aggregate for making concrete.

- $\quad$ Fine aggregate gradation is ideal for concrete mixes ie zone 2 (ideal zone). Based on several tests, the ratio of iron sand waste and bottom ash which is the closest to the gradation of zone 2 (ideal zone) is the percentage of the iron sand waste mixture of $40 \%-60 \%$ bottom ash that enters zone 2 (rather rough).

- Based on the results of the slump test obtained ranging from $8 \mathrm{~cm}-10 \mathrm{~cm}$, whereas in the design of concrete mix (mix design) $10 \pm 2 \mathrm{~cm}$, the value of the slum test has met the plan.

- The results of the calculation of concrete density obtained are close to the planned specific gravity of $2,383 \mathrm{~kg} / \mathrm{m}^{3}$, and the specific gravity of this concrete is included in the normal concrete category which has a volume weight between $2200 \mathrm{~kg} / \mathrm{m}^{3}$ to $2500 \mathrm{~kg} / \mathrm{m}^{3}$.

- $\quad$ The compressive strength of the average age of 28 days reached the characteristic compressive strength of f'c 20 Mpa but did not reach the compressive strength of the plan that is f'cr $32 \mathrm{MPa}$.

The results of this study stated that bottom ash and iron sand waste could be used as a substitution of fine aggregate in the manufacture of concrete. The percentage of fine 
aggregate used is the percentage of iron sand waste $40 \%$ $60 \%$ bottom ash. The specific gravity concrete, including normal concrete density.

\section{Suggestions}

Suggestions that researcher can tell about this Research are:

- For a coarse aggregate a varied size of $0.5 \mathrm{~cm}$ up to 4 $\mathrm{cm}$ material is used in order to obtain a better quality of concrete.

- Further Research needs to be done on the gradation of the percentage of iron sand and bottom ash that is completely (perfect) in zone 2 (ideal zone) .

- Further Research needs to be done by adding admixture to concrete mixtures by using iron sand waste and botoom ash so that the compressive strength of concrete is higher.

\section{REFERENCES}

[1] Alzaed, A. N. (2014). Effect of Iron Filings in Concrete Compression and Tensile Strength. International Journal of Recent Development in Engineering and Technology, 3(4).

[2] Arinata, A. S., Hidayat, M. T., \& Wibowo, A. (2014). Pengaruh campuran kadar bottom ash dan lama perendaman air laut terhadap kuat tekan pada silinder beton (The effect of a mixture of bottom ash levels and sea water soaking time of compressive strength in concrete cylinders). Jurnal Mahasiswa Jurusan Teknik Sipil Universitas Brawijaya .

[3] Bajare, D., Bumanis, G., \& Upeniece, L. (2013). Coal combustion bottom ash as microfiller with pozzolanic properties for traditional conrete. Procedia Eng, 57, $1387-1391$.

[4] Darwis, Z., Soelarso, \& Hidayat, T. (2015). Pemanfaatan limbah bottom ash sebagai substitusi agregat halus dalam pembuatan beton (Utilization of bottom ash as a substitution of fine aggregate in the manufacture of concrete). Jurnal Fondasi, 4 .

[5] Dayalan, J., \& Beulah, M. (2014). Effect of Waste Materials in Partial Replacement of Cement Fine Aggregate and Course Aggregate in Concrete. International Journal of Inventive Engineering and Sciences (IJIES), 2(4).

[6] DPU. (1990). SNI 03-1968-1990 - Metode Pengujian Tentang Analisis Saringan Agregat Halus dan Kasar (Testing Methods About Fine and Coarse Aggregate Filter Analysis).

[7] DPU. (1990). SNI 03-1970-1990 - Metode Pengujian Berat Jenis dan Penyerapan Air Agregat Halus (Method for Testing Specific Gravity and Fine Aggregate Water Absorption).
[8] DPU. (2000). SNI 03-2834-2000 - Tata cara pembuatan rencana campuran beton normal (The procedure for making a plan of normal concrete mix).

[9] DPU. (2008). SNI 2417: 2008 - Cara Uji Keausan Agregat dengan Mesin Abrasi Los Angeles (How to Test Aggregate Wear with a Los Angeles Abrasion Machine).

[10] Ghannam, S., Najm, H., \& Vasconez, R. (2016). Experimental study of concrete made with granite and iron powders as partial replacement of sand. Sustainable Materials and Technologies, 9, 1-9. doi:https://doi.org/10.1016/j.susmat.2016.06.001

[11] Kumari, S. L., \& Thandavamoorthy, T. (2017). Development Of High Performance Concrete Using Bottom Ash As Fine Aggregate. International Journal of Civil Engineering and Technology (IJCIET), 8(12), 354-361.

[12] Lutfi. (2012). Penggunaan Pasir Besi Sebagai Pengganti Semen Terhadap Kuat Tekan Dan Kuat Tarik Belah Beton (The use of iron sand as a substitute for cement against the compressive strength and tensile strength of the concrete). Media Bina Ilmiah Bina Patria, 6(2).

[13] Manhas, S., \& Moohmend, A. (2018). A Research - Vaguely reaplacement od aggregate with GGBS in concrete. International Journal of Civil Engineering and Technology (IJCIET), 9(3), 65-69.

[14] Menéndez, E., Alvaro, M., Hernández, M. T., \& Parra, J. L. (2014). New methodology for assessing the enviromental burden of cement mortars with partial replacement of coal bottom ash and fly ash. J. Enviro. Manage, 133, 275-283.

[15] Ramadevi, K. (2017). A study on properties of concrete with ceramic waste replaced for fine aggregate. International Journal of Civil Engineering and Technology (IJCIET), 8(8), 1730-1737.

[16] Ramesh, K., Lokeswari, S., \& Ravitheja, A. (2018). A experimental study on utilization of waste foundry sand in concrete as a fine aggregate. International Journal of Civil Engineering and Technology (IJCIET), 9(3), 80-89.

[17] Ramzi, N. I., Shahidan, S., Zulkhairi, M., Maarof, \& Ali, N. (2016). Physical and Chemical Properties of Coal Bottom Ash (CBA) from Tanjung Bin Power Plant. IOP Conf. Series: Materials Science and Engineering 160.

[18] Ravindrarajah , R. S., \& Tam, C. T. (1987). Recyling concrete as fine aggregate in concrete. The International Journal of Cement Composites and Lightweight Concrete, 9(4).

[19] Singh, M., \& Siddique, R. (2013). Effect of coal bottom ash as partial replacement of sand on properties of concrete. $J$. Clean. Prod, 620-630.

[20] Sreenath, S., \& Harishankar, S. (2016). Effect of partial replacement of fine aggregate in concrete with low density polypropylene. International Journal of Civil Engineering and Technology (IJCIET), 7(6), 635-640.

[21] U.S. Environmental Protection Agency (EPA). (2007). "Human and Ecological Risk Assessment of Coal Combustion Wastes" (draft). (Released as part of a Notice of Data Availability). 